\title{
Refractory Primary Cutaneous Diffuse Large B-Cell Lymphoma, Leg Type
}

National Cancer Institute

\section{Source}

National Cancer Institute. Refractory Primary Cutaneous Diffuse Large B-Cell

Lymphoma, Leg Type. NCI Thesaurus. Code C138028.

Primary cutaneous diffuse large B-cell lymphoma, leg type that is resistant to treatment. 